\title{
Corruption as Cankerworms towards Economic Development in Nigeria
}

\author{
Ibrahim Suleiman $^{1}$ \\ ${ }^{1}$ Department of Political Science, Bauchi State University, Gadau, Nigeria \\ Correspondence: Department of Political Science, Bauchi State University, Gadau, Nigeria, E-mail: \\ isuleiman@basug.edu.ng
}

Received: September 13, $2017 \quad$ Accepted: September 15, $2017 \quad$ Online Published: September 21, 2017

\begin{abstract}
Corruption has been corrosively eating the fabrics of the Nigerian nation. Its persistence in the form of fraud, mismanagement, misappropriation, diversion of public funds, tax evasion, money laundering etc. has led Nigeria into unfortunate national and even international circle of criminal minded persons. This therefore has made the development of the country and its attendant benefits only a paper work or rather an illusion. This paper conceptualizes corruption beyond the point of public officers taking bribes and gratification, committing fraud, stealing public funds and assets to equally include, deliberate violation of standards for gainful ends which may be in cash or kind. It therefore, encompasses any decision, act or conduct that is considered pervasive to democratic norms and values. The method utilized by this work is incidence analysis and documentary research. The paper which is divided into five sections concluded that, only anti-corruption policies and programs anchored on ethical, balanced, independent, and self-sustained, people oriented can succeed in Nigeria and thereby ensure national economic development. The paper recommended among other things for a successful anti-corruption crusade in third world countries that, international agencies such as Paris Club, IMF, World Bank, UNO should review their policies and conditions to reflect war against corruption especially among third World leaders even while in office. That a mandatory involvement of all community based organizations be considered in annual budget formulation, monitoring and evaluation to avoids misappropriation and looting in the country.
\end{abstract}

Keywords: Corruption, Cankerworms, Economy, Development, Nigeria.

\section{Introduction}

Corruption is a global phenomenon and its effect on individuals, institutions, countries and global development has made it an issue of universal concern. Although the concept has no universally accepted definition, yet, this has not debarred a collective condemnation of its practice (Ikubaje, 2004).

With the adoption of new constitution on May 29th 1999, the civilian administration identified massive corruption in governance and business as one of the areas that required urgent attention. This necessitated the establishment of Independent Corrupt Practices and other Related Offences Commission (ICPC) and Economic and Financial Crimes Commission (EFCC) to combat the menace of corruption in Nigeria. 
Corruption could be described as any practice, act or omission of a public official that is a deviation from the norm and cannot be openly acknowledge, but must be hidden from the public eye corruption diverts official (unofficial) decision-making from what a decision should have been to what it should not have been and is not limited to public sector, it permeate all our socio-economic life. In this manner, the report of the political bureau which the federal government of Nigeria set up in 1987 sums it up thus:

"Manifestation of corruption include the inflation of government contracts in return for kickbacks, frauds and falsification of account in the public services; examination malpractice in our educational institutions including universities; the taking of bribes and perversion of justice among the police, the judiciary and the various heinous crimes against the state in the business and industrial sectors of our economy, in collusion with multinational companies such over-invoicing of goods, foreign exchange swindling, hoarding and smuggling".

In this vain, corruption is a phenomenon that has become a matter of great concern to Nigerians, especially as it has pervaded all levels of government and civil society. Thus, executive and legislative arms of government, the judiciary, religious institutions, the school system, law enforcement agencies, in fact no part of the Nigeria society is spared of the cankerworm of corruption. Therefore, combating corruption is a necessary step towards economic revamp. Different degrees of corruption are inimical and antithetical to development aspirations of Nigeria. As it has amply been demonstrated in various sections of the Nigerian state, the illegal and abusive squandering of state and local government resources by a few selected or elected political officials deeply hurt any genuine efforts to develop those states or regions.

In this presentation, corruption is conceived in the widest possible sense, to include fiscal, environmental and policy fraud. It is clear that corruption with impurity has been the bane of various regimes in Nigeria since independence and every attempt at checkmating abuses and wrongdoing by public office holders would not be happily accepted. This paper attempts to critically analyze corruption curtailment in transforming the Nigerian economy. In doing this, incidence analysis and documentary research were employed. Efforts made in transforming the Nigerian economy so far and the challenges facing the current reform are also highlighted. To achieve this, the paper is divided in to five sections. While section one introduces the paper, the second section reviews some literature and theoretical issues. Section three discusses the causes and effects of corruption. Section four reviews the anti-corruption programmes in Nigeria against expectation. The last section concludes the paper and proffers some policy recommendation.

\section{Literature and Theoretical Issues}

Corruption has been an abrasive and carcinogen corrosively eating the fabrics of the nation. The persistence of corruption and related fraud, mismanagement, misappropriation and theft that, has led to the unfortunate conclusion in national and international circles that Nigeria is a major money laundering centre, and Nigerians are criminal minded and preoccupied with crime and fraud.

Corruption covers a wide range of behavior, which deviates from the formal duties of a public role because of a private gains regarding (personal, close family, private clique, pecuniary or status gain. Or it is a behavior, which violates rules against the exercise of certain type of duties for private gain (Nye, 1976). Thus, corruption include such behavior as bribery (use of reward to pervert the judgement of a person in a position of trust); nepotism (bestowal of patronage by reason of ascribtive relationship rather than merit); and misappropriation (illegal appropriation of public resources for private uses). 
Corruption means, more public officers are involve in taking bribes and gratification, committing fraud and stealing funds and assets entrusted to their care. It is the deliberate violations for gainful ends, of standard of conduct, legally, professionally or even ethically established, in private and public affairs. Usman, (2001) further assert that these gains may be in cash, or kind or it may even be psychological, or political, but they are made from the violation of the integrity of an entity and involves the subversion of its quality and capacity

On the other hand, Oboyega, (1996) notes that corruption encompasses any decision, act or conducts that is pervasive to democratic norms and values. It also covers any decision, act or conduct that subverted the integrity of people in authority or institutions charged with promoting, defending or sustaining the democratization process, thereby undermining its effectiveness in performing its assigned roles. It is obvious that corruption manifests in various forms. It occurs when one obtains a business from the public (private) sector through inappropriate procedure; it occurs when one is exempted from the application of certain laws or regulations and when one is given undue preference in the allocation of scarce resources. Therefore, regardless of the mode it occurs, its impact is always negative in the societal development.

This prompted Achebe, (1988) to assert that "corruption in Nigeria has passed the alarming and entered the fatal stage, and Nigeria will die if we keep pretending that she is only slightly indisposed.

Corruption ,as put by Joseph, (2002) can be viewed from the "fraud triangle" consisting of pressure, opportunity and rationality, which is the result of fundamental systemic and system failure, such that individuals, structures, and institutions, helplessly on the one hand and will fully on the other, fall prey to its various admittedly vagarious conflicting complex dimensions. Act of corruption became normalized to the extent that it is abnormal for anybody to raise any form of personal, legal or institutional alarm against it. The following model explained this relationship.

Figure 1

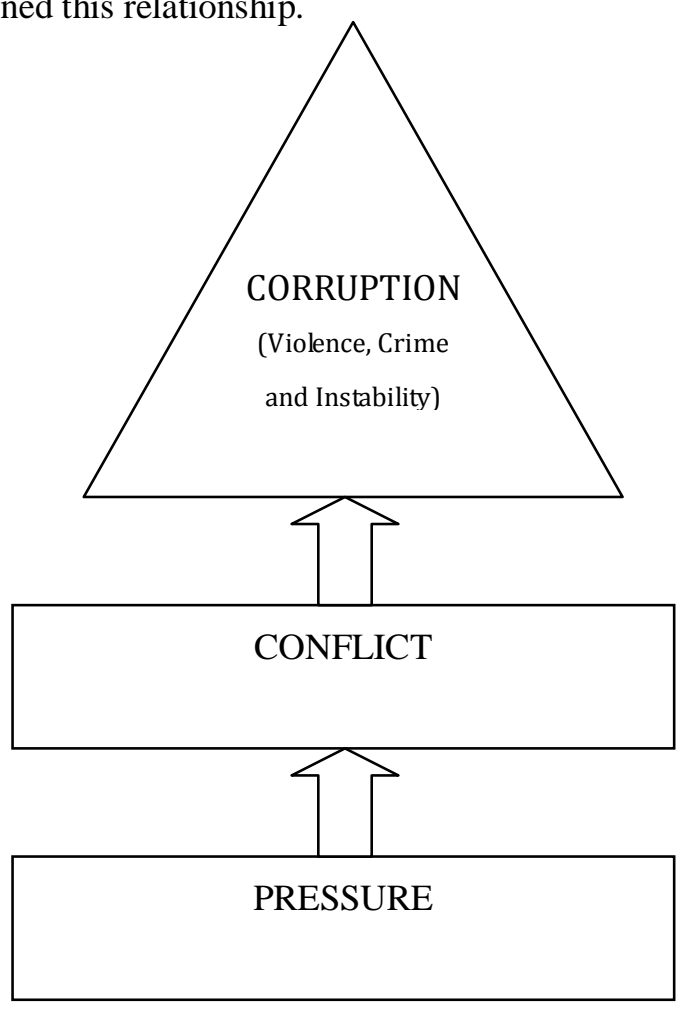

Source: Joseph T. 2002 
From figure 1, at pressure level, individuals and interest groups seek available system. Wide values and norms and directly or indirectly pressurize the system to allow corruption to thrive in manifold forms by providing the rationality and tacit modes of accepting it as normal and justifiable. Sadly however, cultural affinity, religious sentiments, ethnicity, regional and geopolitical alignment are mobilized to construct, deconstruct and reconstruct the reality and seriousness of corruption and allied criminal behaviours in the society.

On the second side of the fraud triangle, the opportunity level, and the prevailing system, produces the prevailing opportunities to commit fraud and corruption as there are somewhat deliberate loopholes created in the way and manner life-enhancing opportunities, legal and administrative systems or machinery and institutional core-responsibilities and duties are administered. Even the enforcement of laws and administration of penal sanctions are constantly altered to benefits those in position of influence. Most time, those who commit crime are not punished and when they are, the punishment does not fit the crime. This precipitates further criminality by those who engage in or want to try the will of the law. Obviously, rising unemployment, poverty, social and economic injustice, political repression, community neglect, alienation and abuse and denial of fundamental human and constitutional right are precipitants of violence, crime and other social vices inclusive of corruption.

Finally, at the level of rationality the combine forces of pressure and rationality produce the rationality and rationalization for corruption and allied crimes. When persons from certain cultural, economic, social, political, ethnic and religious backgrounds are indicted or arrested for involvement in acts of corruption, such primordial connections are put to work to prevent the prosecution of such individuals, because, according to these logic, they are 'one of us/ours'.

All these issues arise essentially from the complex and conflict nature of our society, since all interest cannot be merged as one. Thus, the bottom line of all acts of corruption, especially when they persist in spite of existing control regimes is the conflicting interests inherent in the society.

Therefore, corruption is not only about money, stealing public funds or receiving gratifications. It is corruption to deny those who won elections their victory, and award victory to those who lost. It is corruption to misuse the apparatus of government, particularly the security agents, to rig elections as was widely done in the general and presidential elections of April, 2003 in Nigeria where some candidates scored more than the total registered voters. It is corruption to claim the result of such elections as mandates from the people.

Corruption includes the deceit of trusting Nigerians whom you promise one thing and do something else. Corruption includes creating situations of uncertainty and stress, for the entire populace to gain selfish advantage. Corruption also includes playing one religion or ethnic group against the other for whatever gain.

Last but not the least, Usman (2001) describes corruption within the Nigeria context as: bribery, extortion, graft, embezzlement, betrayal of trust, unfair advantage, financial malpractices, dash, gratification, brown envelopes, tips, emoluments, greasing, softening the ground, inducement, sub-payments, side payments, irregular payments, payments under the table, undocumented extra payment, facilitation payments, mobilization fees, revised estimates, padded contracts, over/under invoicing, cash commission, kickbacks, pay-offs, covert exchanges, shady deals, cover ups, collusion $10 \%$ rule (bribe sub charge), 50\% rule (sharing bribe within the hierarchy), let keep our secret, highly classified transaction, vested interest, 
customary gift giving, tribute culture, nepotism, indiscipline and disrespect to society.

\section{Causes of Corruption}

Rose-Ackerman (1997) provided six causes of corruption:

\subsection{Bribes that equates supply and demand}

Through corruption, government officials exercise monopoly of power by determining the quantity of services provided. Like a private monopoly, officials may set the supply of services below the official sanctioned level to increase economic rents. Conversely, corrupt officials may increase the supply of service if the government has set the supply below the monopoly level. In other situation, the service is not scarce but is, like a passport, driver license, or pension available to everyone who qualified for it.

However, corrupt officials may have sufficient monopoly of power to create scarcity either by delaying approval or by withholding them unless bribes are paid.

\subsection{Bribe as incentive payments for bureaucrats}

Bribes often act as an incentive payment to public officials, but tolerance of these payments, especially by outside lenders and donors such as the World Bank, is likely to dim the prospects for long term reform. Incentives payments that are widely viewed as acceptable should be legalized, but not all incentives pay schemes improve bureaucratic efficiency. Instead, they encourage inefficiency to maximize financial rewards. For example, pay offs to queue managers can be efficient because they create incentives for the managers to work quickly and to favour those who value their time highly.

\section{3 Bribe to lower costs}

Governments impose regulations, levy taxes and enforce criminal laws, individuals and firms may pay for relief from these costs. For example, by colluding with tax collector and custom official to lower the sums collected. The economic impact of bribe paid to avoid regulations, lower taxes, and supersede laws depends on the efficiency of the underlying systems and also the western multinational cooperation companies are used to bribing and lobbying politicians to seek favours and profit.

\subsection{Bribes to obtain contracts and concessions and to private firm}

Bribes paid to win major contracts and concessions and to privatize companies are generally the preserve of big business and high level officials. Such bribes appears analogous to cases in which government disburses a scarce benefit. Bribing the top officials can have far reaching economic consequences. Consider a logging concession that a company obtains illegally over the higher bids of its competitors.

If corruption does not restrict who bids and if the official granting the concession can not affect its size, then the firm that pays the largest bribe, value the concession the most. The lost revenue from the higher bids, however, will be felt in the form of higher taxes and cancelled public programmes. The payoff may be "just" a transfer, but it is harmful to the well being of the ordinary citizens. Typical examples are how Nigerian crude oil export records which remain questionable and many fake firms were awarded contract against the ethics of contract awarding policy or law.

\subsection{Bribes to buy political influence and votes}

Contrary to the principles of democracy, many corrupt politicians coming to power even through citizens are aware of their malfeasance. Moreover, bribes are often used to fund political parties at election campaign due to the fact that modern political campaign particularly in Africa require enormous amount of money. In the absence of the public funding, businesses that have a stake in politicians decisions are the most convenient source of funds. 
Even if certain contribution from businesses is legal, firms and politicians may prefer to keep them secret if a quid proquo is involved and entrenchment system of illegal payoff can undermine efforts to reform campaign financing. For example many business tycoons had immensely contributed to the success of PDP and Obasanjo in particular. Notable among them are AlikoDangote who gave out two private Jets and token of Five hundred million approximately as a donation to clear ground for his business (Daily Trust, 13, 2003. P.14).

\subsection{Bribes to buy judicial decision}

Through their decisions judges have the power to affect the distribution of wealth. Thus, like any public official with similar powers, they may be tempted to accept bribes. This temptation is stronger when judges are underpaid and overburdened and have poorly equipped and unstaffed offices.

Even if judges are not themselves corrupt, clerks in charge of assignment cases and advising judges may demand or accept bribes. In African countries, particularly Nigeria, judicial bribe to buy decisions has been exposed. Election petition tribunals of the then presidential and gubernatorial elections were found wanting of collecting bribe from the ruling party as a reward for judging a case in their favour (Daily Trust, September, 20, P.18).

Gurin, (2003) came up with three principal moral causes of corruption in society which includes;

\subsubsection{Utilitarianism}

Utility is one of the dominant moral principles of materialistic civilization. The ideas of utility is that the only pursuits which man should undertake in life of those that bring immediate material, gain or profit to him as an individual or as a member of a particular group representing certain material interests.

In these pursuits, moral standards that could be tolerated are those that extol man's 'freedom' or 'right' etc enrich himself or surround himself with material largesse obtained; mostly at the expenses of others. Thus only such 'moral' standards as profit, individualism, comfort and freedom is accepted as the fundamental norms of life.

Higher ideals and moral principles are given to place with the result that society loses standard, moral value upon which to act. Values, standards and norms keep on changing according to the turns of fortune in the pursuit of gains and profits. People who believe in utility are always ready to compromise with every system; they exhibit wonderful capacity adaptability according to changing circumstances,. They can work for any ideology; fight under any flag and die or kill for any cause provided they have something to gain whether the profit to be had is negligible, or even doubtful.

\subsubsection{Material Progress}

The quest for material progress to the total neglect of all other goals of human existence is another feature of corruption. To achieve this goal the entire societal machinery include literature and 'scientific' thoughts are geared towards convincing individuals that the man of worth is the rich man, that the ultimate purpose of life is to attain the limit of material and sexual pleasures.

Consequently- theories are formulated to 'prove' that the whole history of man is the struggle to get bread, eat, drink and be married; and that man is directed only by his instincts, the most important of them being the instincts or hunger and sex; in other words, the ultimate aim of human existence is to be materially and sexually happy in this world even if it involves the annihilation of the rest of mankind.

As one scholar writes; So strong indeed is our addiction to wealth, so confirmed our belief that it is wealth which above all other things, confers merit upon a man and greatness upon a man and greatness upon a 
state, that it has succeeded in inspiring two theories of the greatest historical importance with regard to the nature of the motive force which makes the wheels of the world go round. One of these laissez-faire economics, dominated in the Nineteenth century.

It asserted that men would always act in the way, which they considered would conduce to their greatest economic advantages; that in short, they were inspired by, hedonism not of the passions, but of the pocket. The other, which bids fairs to dominate the early part of the twentieth century is Marx's theory of economic determinism, which insists that the way in which, at any given movement, a society Organizes its economic system to satisfy its material needs, determines its arts, its ethics, its religion, and even logic, no less than its form of government.

Both these theories derive their greatest plausibility from the value which men and women, demonstrably place upon wealth as a criterion of merit in individuals and a sign of greatness in state.

\subsubsection{The God Denial}

Denial of God is another main feature of materialism. Materialism denies God not because He is really not there, but because the decrees of God conflict sharply with the interest the materials are out to protect. The dialogue between Prophet Shu'aibu (A.S) and his people who were materialist and who are bent upon promoting their worldly interest at all cost will serve as a god example. "To the people of Madyan (we sent) Shu'aibu one of their own brethren; he said "O my people! Worship God: You have not other god but Him. And give not short measure or weight; I see you in prosperity. But I fear for you the penalty of a day that will compass (you) all rounds. And O my people gives just measure and weight. Nor withhold from the people the things that are their due; commit not evil in the land with intent to do mischief (Corruption).

Thus, corruption; Profiteering, cheating exploitation and confiscation of people's property in the name of business are against the law of God and are incompatible with Relief in, and worship of God.

4. Some Effects of Corruption

In Africa, and indeed Nigeria corruption has severely undermined national, social and economic development. In fact, corruption often leads to national collapse as witness by the former Zaire and Somalia, where nepotism led to self-immolation.

Almost every change of government, violent or peaceful, in the continent is driven by pledges to get rid of corruption. Indeed, corruption has led to

Africa's political instability and gross abuses of power. To be more specific, corruption has led to bad roads and decaying infrastructure, inadequate medical services, poor schools and falling education standards, and the disappearance of foreign aid and foreign loans and of entire projects without a trace (or their delayed completion, leading to higher costs).

Corruption has meant that fewer imported goods enter the country than were paid for; foreign exchange earned from exports is not repatriated; national assets are run down and ruined; production capacity in industry; agriculture, and services have been reduced; and repairs of buildings, equipment, vehicles, and physical and social infrastructure have been paid for repeatedly but never performed.

Corruption distorts the economy it led to waste and misallocation of resources. Citizens' fundamental needs- food, shelter, health, education are neglected. Thus corruption creates an artificial need for external assistance to compensate for corrupt and irresponsible mismanagement for local resources. Having created the need, corruption then impedes foreign assistance. 


\section{Anti Corruption Programmes in Nigeria}

In order to curb this cankerworm, various governments in Nigeria have responded to the problem of corruption by implementing one. Programme or the other, and these include Ethical Revolution, National Orientation, and Waragainstin discipline, Mass Mobilization for Self-Reliance and Economy Recovery (MAMSER). Despite all these efforts by various regimes to find solution to the problem of corruption, this problem (corruption) seems to be defiling all these curative mechanisms put in place by various governments. This situation prompted President Obasanjo when he came to power in 1999 to declare war against corruption, if Nigeria will make progress in all facets of the state. Since, the social and economic approaches which other regimes adopted seemed to have failed he opted for legal instrument to combat corruption. Independent Corrupt Practices and Other Related Offences Commission (ICPC) and the Economic and Financial Crime Commission (EFCC) were instituted by the regime in combating corruption in Nigeria.

To appraise critically the consistency or otherwise of these anti corruption programmes, the incidence analysis that requires the use of descriptive and inferentive tools or explained early is employed.

Musa (1983) believed that "The most powerful civil servants, military officers, police officers, judges, politicians, academia and journalist who have shaped and shaping the destiny of this country, since independence, when they "retire" almost in all cases retired in to company board-rooms. Here, they operate as shareholders, directors, Chairmen, Consultants, or as Landlords, contractors, renters and other form of commission agents, and front-men for foreign business interest operating in Nigeria. They get these positions not out of charity of these business interest operating in Nigeria, when they held public office and continue to use their inside knowledge and contacts in government to shape public policy to serve these vested interest.

The INEC Chairman in 2003 spent billion of Naira promising to get Nigerians a digital voter's register that will last 50 years, and the Data capture machine had not even arrived INEC office when some of them were found in political chieftains homes. Moreover, some bribe paid to members of the Na'Abba led House of Representatives by the then Executive was dumped as evidence of corruption upon table in the House by some of its members. What was the action taken by the anti corruption agencies? What happened to power project contract issued and fully paid to non-existing companies? What is the explanation for failure to pursue and prosecute those involved? (Awoniyi, 2003).

In another occasion, Ribadu (2006) in his report of corruption practices against the then vice president, Atiku stated that Globacom Limited license was paid for, after public money in the Petroleum Technology Development Fund had place 15 million Dollars deposit in the Equatorial Trust Bank (ETB). While Onyinke (2006) in her testimony before the House of Representatives Committee on Capital Markets, noted that Obasanjo subscribed to 200 million shares in Transcorp which were held in the blind trust by Obasanjo Holdings Limited. However, in support of Transcorp, President Obasanjo (2006) argued that it was formed as "Nigeria's emulation of a step already taken latest successful industrial countries like China, South Korea and India.

It was argued that although, there is the need to create indigenous bourgeoisie, to compete in the global economy, but such need should not be done in a clientele manner. Nigerians are frowning at the composition of the Transcorp membership and are raising questions on the source of the huge fund being used to acquire the company's assets. The corporation, it is observed is populated by those described as 
acolytes of the present, most of whom applaud the reform policies and supported his unsuccessful bid for a their term (Odunlami, 2006).

Corruption has cost our nation an estimated 600 billion dollars ever the last 40 years (Global News, 2011). Economists wonder if this figure is simply hard cash or has been calculated to include the amount of economic value that money could have generated. When correctly invested, N1 could generate as much as N5 of economic values, depending on the national bank reserve rate. Therefore, if the $\$ 600 \mathrm{bn}$ is simply in hard cash, then Nigeria might have lost as much as \$ 3 trillion in economic value over the last 40 years (The Economist, 2007).

Courtesy of corruption, the rich are becoming richer while the poor becomes poorer. Poverty remains widespread in the country with as much as $70 \%$ of the total population living on less than one US dollar per day. Human development Index (HDI) showed that Nigerian was ranked 151st out of 174 countries in the world and 22nd out of 45th African countries (UNDP, 2008).

In conducting the 2011 General Election, why did the INEC Chairman abandon the NDA finger printed voter register obtained in countrywide registration that took place in January/February, 2011 for the manual register for the election after so much money were spent getting those equipments and personnel in place?

6. Conclusion and Recommendation

The position of the paper is that any anti corruption policy or programme that wants to build independent, balanced, self-sustained and people oriented national economy should be anchored on ethical issues. How can we hate corruption as a people and yet process the documents that make so much of it possible on a daily basis? Why do we claim believing in God as Muslims and Christians yet acted against HIS injunctions by modifying and destroying his divine arrangements and eternal will? Is the God we worship not too good to do anything evil and too wise do anything foolish?If yes why hatred, animosities and even the killings of fellow beings by fellow beings? Is our action not opposing the God's we say is perfect? Are we not guilty of moral corruption? Can't we see sense in the perfect designer who made us in one nation? Can we change the unmistakable arrangement? Curtailing corruption lies within answers to these questions. Thus, unless we honestly and squarely answer these questions, every Nigerian would continue to drink from the evil cup of corruption.

In conclusion, if Nigeria is to make progress, corruption must be curbed to tolerable proportions, what Johnson calls low-corruption equilibrium. Corruption is the major obstacle to progress in Nigeria, and that its effect on development is disastrous. We must act therefore, and without delay, focusing our effort on eradicating large scale corruption.

To eradicate corruption and for Nigeria to seriously progress, the following recommendations should be vigorously pursued.

- A careful study of the pattern of official fiscal allocations, donations and expenditure towards the amelioration and overall development of the nation with a view to sanctioning previous or past misapplication and mismanagement of funds by all parties involve.

- Government should make the disposable of corruption proceeds and launder of it into the economy and society impossible for perpetrators. That is, banks, other financial institutions and businesses as well as international judicial and legal institutions must be employed in an integrated manner to enhance the repatriation of proceeds of corruption and punishment of offenders. 
- International donors like World Bank, Paris Club, Transparency International, International Monetary Fund (IMF) etc. should amend their policies and conditions to curb or reflect anti-corruption war against Third World Leaders while administering the loans.

- A mandatory involvement of all Communities in budget monitoring and evaluation to avoid misappropriation and looting is equally relevant in this regard. This should be part of the nation's fiscal policy.

- Leaders should inculcate moral discipline, accountability, consider legal and institutional reforms and political and economic adjustment, reducing incentives for pay offs, establishing credible and independent judiciary, reform civil service to suit domestic and global changes as well as ensuring absolute freedom for press and access of knowing government's financial affairs at any time.

\section{References}

Achebe, C. (1998). The Trouble with Nigeria Enugu, Fourth Dimension Publishers.

Awoniyi, S. (2003). Aso-rock Villa the Fountain of Corruption, African Press Ibadan

Daily Trust News paper (2003). Contribution to PDP and Obasanjo, 13 June, P.14 and P.18

Gboyega, A. (1996) .Corruption and Democratization in Nigeria, (ed), AgboAreo Publishers, Ibadan.

Global News (2011). Massive lost Due to corruption, September, 2 P.3-9

Ikubaje John, G. (2004). Anti-corruption Initiative and Corruption Survey Report in Nigeria; The Challenges and the Way Forward, CDD's Project.

Joseph T. Wells Encyclopedia of Fraud (2002) Austin, Texas, Obsidian Publishing Company Inc.

Musa, B. (1983).Our struggle for a New Social Order in Nigeria: Nigerian Democratic Review. Action Centre Information and Documentation Ibadan.

Nye, J. S. (1976).Corruption and Political Development: A case - Benefit Analysis.The American Political Science Review.

Onyiuke, N. O. (2006). Obasanjo subscribed to 200 million shares. This Day, September, 14.

Obasanjo, A. O (2006).Nigeria Emulate Latest Successful Industrial Countries. The News, July, 17,

Odunlami T. (2006).Baba's Boys and their Deals, The News, July, 17, pp.20-22

Rose, A. (1997).Corruption and Development in Boris Pieskovic et al (ed): Annual World Bank Conference on Development Economics Washington D.C.

Ribadu, N. (2006).Atiku Release 14 Cheques Paid to PDP, Others. This Day, Sept. 14

The Economist (2007).A Nation in Waiting, View from broad. Sunday Trust, Oct. 28, P, 39.

Usman Y.B. (2001).Some Observations on the Problem of Corruption in Nigeria from a Historical Perspectives.The Nigerian Institute of Advanced Legal Studies. Abuja

UNDP $(2002 ; 2008)$ Report on Nigeria

\section{Copyrights}

Copyright for this article is retained by the author(s), with first publication rights granted to the journal. 